\title{
Playing Safe: The Writer behind the Text of Wuthering Heights
}

\author{
Sara Saei Dibavar (Corresponding author) \\ Faculty of Letters and Humanities \\ Shahid Beheshti University, Tehran, Iran \\ E-mail: saei_sarah@yahoo.com \\ Shideh Ahmadzadeh \\ Associate Professor, Faculty of Letters and Humanities \\ Shahid Beheshti University, Tehran, Iran
}

Doi:10.7575/aiac.alls.v.5n.3p.1

Received: 02/04/2014

URL: http://dx.doi.org/10.7575/aiac.alls.v.5n.3p.1

Accepted: 03/05/2014

\begin{abstract}
In Wuthering Heights, Brontë provides us with the opportunity to meet two writing subjects; Emily Brontë herself and her character Catherine Earnshaw. Both these writers resist and challenge the authority of the patriarchal. Their different methods of interaction, though, cause one to fail and the other one to succeed. The objective of this paper is to have a look at the strategies that culminate in such a result from a Kristevan viewpoint. Findings indicate how Brontë can, unlike Catherine, play successfully with ideas in the text, sublimate her desires through her metaphors and finally achieve a sense of jouissance by playing at the borders without being entrapped in the forbidden realm of the abject. In addition, it is discussed that through metaphors, Brontë simultaneously establishes and demolishes the codes of an apparently accepted patriarchal world in the symbolic territory, destabilizes the text and deconstructs the fake reform of the ending of the story while constantly remaining on the safe side.
\end{abstract}

Keywords: Subject in Process, the Writing Subject, Metaphors, Transgression, Sublimation

\section{The Writing Subject and the Text}

Postmodern psychology often distinguishes two different orders in the world; symbolic and semiotic. While the former is regarded as the realm of father/law in which one finds an identity, the latter is considered to be a more genuine/maternal order which abounds with drives. Having spent a desire-free period among abundant drives in the maternal phase, the child passes the threshold and becomes a desiring subject within the symbolic order. In other words, $\mathrm{s} /$ he is "inserted in the symbolic order" (Moi, 1985, p. 168) where s/he finds an identity, but should struggle endlessly in order to survive without feeling stuck until death. Studies in this case have attracted so many positive and negative attitudes. Julia Kristeva, for instance, believes that too much of living in the whole scale symbolic world, "a temporal order" (Kristeva, 1986, p. 153), frustrates the soul of a living subject and makes her/him desirous of a return toward the semiotic and the jouissance s/he may find there. However, she warns, there is always the threat of dissolution in case of such a return to the imaginary and the semiotic.

The looming presence of a semiotic dissolution will always haunt the subject who wants to preserve itself through its symbolic identity. Gounelas clarifies this dilemma by mentioning that "[A]s being human means being constantly threatened by engulfment, the only option is to attempt to master it before it masters you, to fling yourself at it, gulp it down voraciously, or, better still, to 'engulf' the mess before it engulfs you" (2001, p. 76). To this purpose, Kristeva's last works have concentrated on possible ways of transgression the subject can benefit from to access jouissance and some sort of free move without endangering its identity and being. So far, the notion of the writing subject has proved to be a viable solution.

"Kristeva's notion of the writing subject suggests a theory of the subject that is dynamic, heterogeneous, contradictory and socially, historically, and ideologically formulated." (Esgalhado, 2002, p. 779) In other words, such a subject is the combination of the conscious and unconscious functions as produced by the language of the text and the circumstances around him or her. The writer, like every other member of the symbolic world is a divided, split subject. Nonetheless, this subject has an advantage: s/he can be shown through the text. This explanation is in turn completed by Oliver when she decides that "such a subject [the writing subject] emerges from a writing that serves as 'a process that moves back and forth between sign and flesh"” (1993, p. 26). Kristevan writer can trespass the boundaries. S/he turns to be a subject in process located on the crossroads of symbolic and semiotic. Since s/he is capable of living on the edge of boundaries, the writer can transmit materials from either side of the semiotic or the symbolic. For an Orpheus, there is "the necessity and viability of an existence at the crossroads." (Letche and Margoni, 2004, p. 50) From time to time, tired of being encircled by repressive codes, this writer takes up "a journey without project, without faith, to the end of the night" (Kristeva, 1982, p. 186). S/he can have trips to the depth of the forbidden and the unspeakable. 
In the semiotic, where drives are ample, and where access to the maternal abundance is achieved, the writer can be granted the jouissance. When $\mathrm{s} / \mathrm{he}$ is released from the fake self $\mathrm{s} / \mathrm{he}$ has to accept, this sense of ample satisfaction encircles her/him. Upon letting go of the symbolic tenuous identity, all that is repressed within this subject bursts out. This is the origin of jouissance; the feeling that one is floating again without having to repress so many for one which is legal, speakable, and unforbidden. Nevertheless, having been in the semiotic for a while, even the writer has to return to the symbolic since this return guarantees her/his being. Without it, s/he would be vulnerable to all sorts of maternal dangers, the most important one of which is the complete loss of this loosened touch on the symbolic. Without the symbolic, there would be nothing. Without it, even the semiotic cannot be defined. Through language, which is the most beneficial instrument of the symbolic, the writer returns. "Having returned, 'I' feels uncomfortable there, but not without a certain sense of gratification" (Kristeva, 1981, p. 164).

The returned writer can impart part of her/his knowledge to others through her/his text. The text $\mathrm{s} / \mathrm{he}$ writes will be sublimated and indicative of her/his experience. At the same time, due to being pluralized, this text will also provide her/him with a sense of fullness. She/he can be multiplied through the voices and the person of her/his characters. All the characters that speak are in fact her/him. This is what expands the writer; what gives her/him the sense of freedom. In an interview, Kristeva expands her notion of the pluralized subject as follows:

I have experienced this myself... that the fictional characters, that all the characters in the novel in some sense represent the writer. There, already, is a polyphonic I. So, when I am the character of a man, of a farmer, or an intellectual, these characters love in different ways. Thus there is a polyphony of relationship as well. So I "pluralize myself" by writing the text. (Midttun, 2006, p. 169)

Kristevan writer "unites maternal and paternal. He is a politician who wants to relate the story of 'desensorilization' to make it "sensible to all participants in the action" (Letche and Margoni, 2004, p. 50). S/he can sublimate the unspeakable. Her/his text is hence a full reservoir of literary images which tell us about the writer. This text can be studied to give way to further discovery of the writer's traces in it. It can be surveyed for its images, metaphors, similes and in short for displaced features to hand in the imprints of its author and his/her psyche.

Brontë's relationship with her text and her mastery over it can be primarily studied by comparing the writer with her major character- and doppelganger- Catherine, whose presence in the novel emphasizes and supports the role of the psychic play in the writer's mind. This character is a representative of Brontë as a writing subject. Ignoring the letters other characters send and receive, she is the only one in the novel whose relationship to books is defined through writing. Catherine's moves in the world of the story represent Brontë's in a larger scale. Both are writers. Both try to create and both are struggling to remove the obstacles. Catherine as Brontë writes out of the desire to record her own thoughts and impose her own meaning on texts. Her power to write, describe and sketch attracts the readers' attentionas apparent in case of Lockwood.

By doubling herself through Catherine, Brontë juxtaposes the two writers- one being the reflection of the other's thoughts. Through the rebellious Catherine, Brontë can materialize her wish of creation within creation. She can delineate how the process of inscription results from not having any other choices. Like Catherine that writes not to feel imprisoned, Brontë also writes in order to get rid of the suppression inflicted upon her as a female member of the nineteenth century English society. Besides, there are affinities in both types of inscriptions because the controlling mind is one. Just like Catherine that writes the margins of the books to produce meaning, Brontë pens the story to gain the upper hand. In both writings, the real is more important than signs. In both, the untouched nature holds certain superiority over the already touched cultural world-- which represents the symbolic.

Catherine's pieces of writing are quite expressive. They show the main piece of Brontë's work. In other words, Catherine's world is a small scale of the world Brontë presents in her novel. Images and themes presented in her text or talk become dominant in Brontë's narrative. For example, imprisonment that is bestowed upon her at the time of writing is later to be announced as an important theme of the story. In Catherine's writing, there are traces of Brontë's story for the reader to pick up. Since Catherine has the generative mind of a writer, she is capable of using images and metaphors. Frost, fire, imprisonment, social role, choice and its consequences are all seen in her writing or talk. These later become dominant themes and notions upon which Brontë skillfully maneuvers by trying to show her two generations in the novel.

Catherine's actions define her preference to change from an other to a subject. Like Catherine, Brontë is also after recognition, even under a pseudonym. Ultimately, both present the impossibility of gaining that status. The only difference between the two that Brontë delineates carefully is through picturing in Catherine what she is not free to do in reality. Brontë chooses Catherine for a rebel after pleasure that is doomed to failure through excess in emotion and aspiring for power. Catherine reverses Brontë in that she follows a different path from what Brontë herself takes. Catherine becomes rebellious while Brontë herself clings fast to the principle of reality and sublimates her desire through finally directing Catherine to her death penalty, which is the destiny for an excess seeker in Kristevan ideology. With the narrative she creates, Brontë experiences the pleasure of being an outlaw through her character while saving herself from the abject allure. Brontë experiences the state of satisfaction while maintaining her life through writing. This is what Catherine does not do when her life is in danger of dissipation. Furthermore, Brontë can generate different 
lives, different voices of her own, and different attitudes to acquire her stability once more while simultaneously pouring out the forces within her by sublimating her desire and by the polyphony of voices which she creates.

\section{Sublimation through Metaphors}

Butler believed that "poetic language is the recovery of maternal body within the terms of language, one that has the potential to disrupt, subvert, and displace the paternal law" (1989, p. 105). This explanation is quite true. Poetic language destabilizes the social code through its own rules. It uses the rules of composition to disturb and destroy the social code while simultaneously strengthening it. Through poetic language, the writer delineates the forbidden in a harmless manner while overcoming her/his fear. This language lets the writer play with codes and established rules through creating unstable meanings, gaps, and displaced figures.

In Kristeva's account, signification is not enough to study the poetic language. For Kristeva, "'narrative' is the recounting of suffering, fear, disgust, and abjection crying out, they quiet down, concatenated into a story" (Kristeva, 1982, p. 145). To Kristeva, what matters is finding release from anxiety and gaining pleasure in writing. Therefore, the text would be written to grant freer rein to semiotic drives in a sublimated, danger-less mode. During the process of writing, the writer moves between semiotic and symbolic. S/he then uses symbolic language as a way to utter the forbidden in an acceptable manner. This movement between sign and flesh is possible because the writing subject maintains a relationship between body and language. Signification will be the result of their simultaneous clash and cooperation since it is "like a transfusion of the living body into language" (Oliver, 2003, p. 39).

In case of poetic language, one will encounter a heterogeneity that proves against fixing meaning. "The feminine doesn't die down or isn't repressed eternally in Kristevan theory, but survives in metaphors. They act "not as flesh desensorialized, turned into words, but as the flesh words that give Orpheus' song its seductive quality" (Letche and Margoni, 2004, p. 50). Metaphor is effective in opening up this hole--this gap--in the text. Using it, dissimilar or opposite things become related. Yet, the nature of this relationship is not specified. Judgments on the nature of its true referent will remain various. Metaphor does not create a single unified meaning to be conveyed in the text. This gap is what gives way to possibilities of meaning in the text and also to complexity of making meaning. This language will destroy beliefs and common ideas through creating music that will not respect the rules. As in case of social discourse, the poetic language will contain both the semiotic and the symbolic, yet the extent of their participation will be different. " [T]he signifying economy of the poetic language is specific in that the semiotic is not only a constraint as is the symbolic, but it tends to gain the upper hand" (Kristeva, 1981, p. 134). Brontë's text, like any other piece of writing shows this tendency of the semiotic through its bountiful images and metaphors.

The primary metaphor in the text is the Gaze. As the subject in process, one is limited within the lines of the paternal dictatorship. Every move of this subject is held in check through the paternal gaze. Like in imperialistic cultures, this gaze who is formed by norms dominates all moves, even the slightest. The indicative of this gaze is metaphorized by Nelly's supervising presence. Buckler states that Nelly is "essential to the establishment of 'the distance between the reader and the people in the novel,' and her purpose is "to control passions, to bring out their meaning and to make them beautiful" $(1952$, p. 81$)$. Nelly surely has a role beyond that. She can properly be said to have the role of the paternal supervising gaze and the observer that interferes and renders the story safe and possible to narrate. As the narrator, hers is the type of a gaze that watches, observes and condemns as soon as one trespasses; her gaze judges and sentences.

Yet, Brontë's narrative betrays this gaze by proving it to be ineffective. There are instances of Nelly's failure in supervision like the time Catherine and Heathcliff enjoy their total alliance on the moors. Furthermore, her incapacity of being in different places at the same time makes her ignorant of what is going on at the Heights. Small narratives help her gather some information to fill out the gaps, something which is not always applicable. Heathcliff's whereabouts at the time of his disappearance, for example, is never to be observed by her. In addition, Nelly, as a character, also misses opportunities of supervision and control. The most obvious instance is her negligence of the second Cathy's actions during her illness.

Failure of the paternal gaze to control is further illustrated through the characters' interactions. Gaze is also the focus of attention in Newman's essay. In her study, she is concerned with female gaze that is compared to that of the Medusa figure. Newman believes that in symbolic patriarchal society, this female gaze should not return the male gaze since it is not tolerated. The simple interpretation is that "to be the object of the gaze-to be spectacle instead of spectator-is to lose one's position of mastery and control-in short, to be emasculated" (Newman, 1990, p. 1032). On the other hand, female gaze finds close association in Kristevan theory with the maternal yearning to rule. In this manner, there is always the danger of imminent eruption of the semiotic drives. As a result, each time this gaze returns the male gaze, maternal desire to rule is disclosed and symbolic dominance, here shown through the patriarchal line, is both disturbed and endangered. Since this gaze promises the disruption of the hierarchal order, it needs to be put back in place through the force of the system.

This tendency of the patriarchal in the novel is manifest through the character of Lockwood. He who has already been agitated by a female look during his short trip before coming to occupy the Grange is now enjoying Nelly's narrative. Newman interprets this action as "listening as a metaphor for looking" (Newman, 1990, p. 1033). During the narration, as Nelly ultimately reveals, Lockwood has the opportunity of looking at Catherine's portrait without the danger of perturbation. Newman states that this text, "articulates the psychological fact that when a woman looks back she asserts her 'existence' as a subject, her place outside the position of object to which the male gaze relegates her and by which it 
defines her as 'woman"' (Newman, 1990, p. 1032). Therefore, through simultaneous presence of Lockwood and the second Catherine, as representatives of two different genders, Brontë can admit and refuse the dominance of the patriarchal symbolic and its tenuous, easily agitated position. Newman's comment on the vigilance of Nelly over Lockwood's gaze, which he thinks is not returned and hence is safe, supports this idea:

But the gaze can serve to destabilize the viewer as well as to confer mastery, especially if the gazer is caught looking by another subject who sees the gaze and perceives it as an expression of desire. For Lockwood, the presumably mastering situation of the looker-on is rendered precarious because Nelly Dean, another vigilant watcher, remarks his plea-sure in looking. (1990, p. 1034)

The maternal gaze can only be tolerated if it does not have the quality of the threatening gaze any more. Nonetheless, even if this gaze is controlled through repression, the possibility of its turning against the norms always threatens.

While presence of gaze dominates as a strong metaphor, image of nature is accentuated through its absence. Homans' essay entitled The Name of the Mother in Wuthering Heights touches on the subject of natural representation in the novel. The literal nature, she believes, is to be kept out of touch in Brontë's narrative. To write about nature and to scamper on the moors are mutually exclusive activities. For both Lockwood and Nelly, the "literal nature entering the realm of textuality would be as fatal to their vulnerable narratives as the snowstorm nearly was to Lockwood's life". (Homans, 1992, p. 347) From Cathy's perspective, nature does not need to be recorded and might, indeed, be diminished by being represented. Cathy wishes to preserve nature from the effects of symbolization. To make signs and to express something in words needs the death of the object since words promise the long lost real object. "Cathy makes her choice for nature, the literal, and therefore implicitly for the unnamed mother" (Homans, 1992, p. 349). The same happens in case of Brontë whose narrator and characters are never to be seen talking about the real nature. This happens while natural images and references are used to the maximum amount. In other words, by comparing the characters to nature-like things, the narrative avoids showing them in real scenes.

In her other essay entitled Repression and Sublimation of Nature in Wuthering Heights, Homans (1978) gives a more comprehensive account of the simultaneous presence and omission of nature in Brontë's text. Her essay emphasizes her formerly discussed idea that while natural images and metaphors are used to extremes in the description of scenes or character attitudes, the real nature is avoided. Dominant examples of such natural presences in the novel are the scenes where characters are likened to natural forces or creatures. For instance, Catherine's character description gains the upper hand when she compares her love for her two lovers: "My love for Linton is like the foliage in the woods: time will change it, I'm well aware, as winter changes the trees. My love for Heathcliff resembles the eternal rocks beneath: a source of little visible delight, but necessary" (Brontë, 1847, p. 121). Likening Edgar to transitory foliage that sparkles at the moment but will soon be diminished is in contrast to what she confesses to be the eternal, steady delight of being at Heathcliff's presence. This idea is further stressed by Catherine's earlier indication that: "whatever our souls are made of, his [Heathcliff's] and mine are the same; and Linton's is as different as a moonbeam from lightning, or frost from fire." (Brontë, 1847, p. 121)

As another example, one can refer to Catherine's description of Heathcliff's nature to Isabella while trying to free her soul from desiring him. Characters' attitudes toward each other are also illustrated through use of natural imagery. Their characteristics are often shown through their connection to natural forces or even creatures or animals. Besides, Homans' meticulous regard toward natural presence in the text draws her attention to natural harmony with characters' attitudes and moods. She illustrates her point through an exemplary passage about nature's obliviousness to Heathcliff's grief over Catherine's death in which a symbol for tears lurks in the image of the dew gathered on the budded branches. Homans does not hesitate to indicate the importance of the turn in the cycle of nature from spring to winter after Catherine's death, which she deciphers as return to "a fully symbolic landscape" (Homans, 1978, p.14).

Traces of Brontë's omissions of nature seen in Catherine's diary fragment are also the topic of discussion in this essay. Lockwood encounters a piece of Catherine's writing which announces her plan to go for a walk on the moor. Nothing else is added to it. Only does the plan seem more agreeable in comparison to the fatigue that will result from getting stuck within the limitations indicated by the house and the dictator. Homans compares these omissions in writer and character's text alike:

Cathy's omission of any description of the romp on the moors is perfectly in keeping with the pattern of Brontë's own omissions, and, further, it suggests a reason for those omissions. Writing creates an order of priority. Ordinarily, a word presents itself as coming first to the reader, putting its referent in second place. The only way to preserve the priority of something is not to have it named, so that what is primary is just that which is left out of the text, and surely these omissions of descriptions of events in nature are significant holes. Everything else about the diary fragment suggests that nature is primary and that writing is intended to be made secondary. (Homans, 1978, p. 11)

Taking this avoidance of literary presentation into consideration, one can propose that nature proves to be the very same semiotic force encircling the boundary of human being. Repressed nature is then the metaphor of the unspeakable that will ruin all should it find its way to the surface. Its elements can be used, its pictures can be drawn, but in itself, it cannot be talked of. Life is restricted to being within the fine line of the symbolic. Short excursions to the heart of nature like "the romps on the moors" which are never narrated can then be taken as trips to the heart of the semiotic. The result of such experiments would of course be jouissance. Homans' own conclusion of her essay supports this idea: 
"We must take the nature that is absent from Wuthering Heights as the ideational representative of something inherently unnamable, perhaps what we call reality, perhaps something else.”(Homans, 1978, p. 16)

The third metaphor is the fire which is the point of resemblance for Catherine's love toward Heathcliff. This metaphor finds meaning through its extended expansion in the text as the metaphor for the force of life. Not only Catherine, but also all the characters in the text as well as the reader are drawn toward it and are disgusted in case they do not find it. This source of life draws Lockwood to itself early in the novel when he is flung back from his living room at the sight of a servant who is trying to make a fire in his fireless fireplace. This fire is what attracts Isabella's attention during her short sojourn in the heights. Unlike the Grange, upon entering the house on the heights, one is inundated by the warmth of the great fire in the fire place. This scene is in utter contrast to the scene which the children see during their early visit to the Grange. In contrast to its artificial magnitude and grandeur, the Grange proves no heaven of Catherine's dreams and hence frustrates her fiery soul, ultimately letting the abjection she is drawn toward engulf her for good.

The idea of being entrapped and lost within narrative is another dominant symbol in the novel. In case of Catherine, the sense of entrapment does not overcome her after she marries Linton. She is born to this idea. As a woman and hence inferior, she has to submit. Yet, in the text, Brontë broadens the idea of entrapment not only for women but also for all the subjects in process. This point of view is supported not only in the text and through its metaphors but also by the text itself as a metaphor. It is emphasized indirectly by many critics when they talk of being entrapped in the text and among its numerous narrative layers and confused relationships. Lockwood becomes the metaphor of the reader who desperately tries to figure everything out. "Passage through the threshold [of Wuthering Heights] will generate a crisis both in the voice of the self and in the logic of a good text." (Jacobs, 1979, p. 49)

Entrapment of the subject is further illustrated in the text through the metaphor of enclosed places:

The reader becomes accustomed to Brontë's habitual use of the image of the house, with its windows and doors variously locked or open, as a figure for varying psychic conditions... the closed house generally represents some sort of entrapment: the body as a trap for the soul... or the trap of society or convention, as when Cathy remains inside Thrushcross Grange while Heathcliff, expelled, watches from the outside and longs to shatter the great pane of glass that separates them. In view of this symbolic system, the preponderance of scenes taking place indoors and the absence or omission of directly represented natural landscape indicate that the condition of the narrative as a whole is some kind of entrapment too."(Homans, 1978, p. 11)

Confinement or being entrapped defines the course of Catherine's life: in childhood, she alternates between the constraint of Wuthering Heights and the freedom of the moors; while in her teens, she is restricted by her injury and has to remain in Thrushcross Grange. Finally in womanhood and because of her choice of a husband, she is destined to confine herself to the deadly calmness of the Thrushcross Grange, from which she escapes into the freedom of death. Only in death is she allowed to take wings toward home, where she truly belongs.

Catherine also fulfills the role of a metaphor and a representative of an outlaw. Her attempts toward dominance and her search for the fiery love of life turn her to one such subject. She can always be talked of but never represented since by loosening her touch on the symbolic, she has given herself up to the forbidden. Her illegal trespass makes her an outlaw incapable of being called back to the symbolic community. Her dissolution, in turn, vows the same destiny for all outlaws. This is the time when the metaphor of the house comes to attention once more. This time, the house is the metaphor of the body and soul of the subject tortured by the vast ample nature around her/him. It "is skewed by extremity: it is an architectural torsion wuthering between stability and instability" (Vine, 1994, p. 340) just like the subject of the symbolic. Its destruction gets along with the dissolution of Catherine's mind that ends with her bow to nature's temptations.

Catherine's submission to symbolic is shown through the metaphor of the mirror. Mirror provides the way to the symbolic in Lacanian definition of mirror stage. The subject that distinguishes itself in the mirror for the first time can then differentiate between itself and its mother. This process leads to its symbolic investment in language as replacement for the maternal loss. It can also guarantee a position for the child to become a subject through submitting to the rules. Though Kristevan analysis differs from Lacanian in that she believes the separation starts prior to mirror stage, she, too, ratifies this phase as an indispensable step in the passage from childhood to subjecthood.

Mirror in Brontë's text becomes metaphoric of this stage in its reverse mode. It acts ironically in exhibiting the subject's dissolution due to loosening its grasp on the symbolic. Catherine who has been physically and mentally sick- due to the fight between Heathcliff and Edgar- experiences a perturbed mental state. Gradually, she feels abandoned by the symbolic-presented by Edgar- through Edgar's negligence. Consequently, she manages to cast Edgar-the representative of the symbolic-off. Therefore, the feeling of loneliness she has always been so afraid of overcomes her. "Deprived of world, therefore, I fall in a faint." (Kristeva, 1982, p.4) She turns to a borderline patient who still mutters disconnected memories of the past; this time she sees her face in the mirror unable to figure it out as her own; "'Don't you see that face?' she inquired, gazing earnestly at the mirror." (Brontë, 1847, p. 161) Nelly covers the mirror with a shawl admitting that it was useless to try to convince her that the image is her own. Since Catherine thinks the face is someone else's, she is so fearful. Fear is intensified as Catherine comes to believe the room is haunted and keeps a steady "gaze towards the glass" (Brontë, 1847, p. 161). This leaves no choice for Nelly except to inform her that she was seeing herself in the mirror: "It was yourself, Mrs. Linton: you knew it a while since." (Brontë, 1847, p. 161) Nonetheless, the rest of Nelly's narration at this point refers to the dissolution of Catherine's mind. As an agitated subject, Catherine is moving backwards in the mirror stage; “'Myself!' she gasped.” (Brontë, 1847, p. 161) 
Her dissipation is initiated through her inability to relate the image to her person. The subject's recognition phase during the mirror stage is hence reversed. This regressive process is in turn continued by her wish for the unity she used to experience at home. The process continues until she rejects herself as a subject by turning Edgar down, admitting her incipient death and wishing to be on the moors soon again. Her symbolic embracing of Heathcliff, representative of the abject maternal, becomes the last step of her regressive process of dissolution. Hence, she reaches a phase where "nothing remains...entire body falls beyond the limit-cadere, cadaver." (Kristeva, 1982, p.3)

\section{From Transgression to Sublimation}

Brontë is successful in showing how her characters face their incessant inner struggle. They fluctuate between hating and resisting the abject, on the one hand, and needing it on the other. Her text also emphasizes the necessity of communication to impart feelings and fears. The language that conveys the need and the desire gains importance in her text. The nature of relationships is essential in Wuthering Heights as well. Wion thinks of the relationship between Heathcliff and Catherine "as a displaced version of the symbiotic relationship between mother and child" (1992, p. 317 8). The story that establishes such a displacement to start with will prove abundant. Characters will get in a row to display different features and choices metaphorically standing for the subjects who experience different ends due to their various relationships to the world. While Catherine displays the subject in process, Heathcliff takes the role of the displacer who displaces everyone and everything. Edgar and his daughter Catherine, on the other hand, are there to guarantee full respect to all norms of the symbolic. Hindley, and his sinking into a void before his sister, foreshadows the fate of a transgressor without a return, a melancholic who has no choice except to sink deep into the void. Lockwood and Nelly are in turn, the sole speakers of the symbolic world who can act as mediatory to bring the sublimated text and its unspeakable message into notice.

Brontë's technique is simple but spectacular. Novel, she shows, can never be written from Cathy's perspective, but from Lockwood and Nelly's who have firmly fixed their places in the symbolic. It cannot also be narrated in Wuthering Heights since it is no place for writing or pinning down time. Unlike the Heights, the Grange which is replete with books proves the unique place for both narration and probable inscription of the story of those who would otherwise have never been captured in the text.

Nelly and Lockwood are the ones who are fully invested in the symbolic. Nelly can use language properly to narrate a passionate story by neutralizing it. This neutralizing process happens in part through the distance she and later Lockwood create by removing the story of its immediacy. That the story is removed from its immediacy and hence is under direct supervision of the symbolic comes from the fact of it is being expressed in words. Language is a replacement for what has been lost. Therefore "the words themselves, there on the page, both presuppose the death of that long line of personages and at the same time keep them from dying wholly, as long as a single copy of Wuthering Heights survives to be reread" (Miller, 1963, p. 393) Furthermore, the narrative is received from hand to hand. Almost all characters except Hareton, Edgar, and Catherine speak or narrate parts of the text. Polyphonic style makes characters find the opportunity to talk. However, there is the major narrator's dominance over the characters in the novel. Therefore, it is the reader who should follow the directions and try not to get lost as Lockwood, the representative of the reader, once did.

The reader of Wuthering Heights must thread his or her way from one interpretative narrative to another-from Lockwood's narrative to Nelly's long retelling ... to Isabella's letter, or to Catherine's dream of being thrown out of heaven, to her interpretation of this in the 'I am Heathcliff' speech, and so on. (Miller, 1963, p. 380)

Nelly as a woman never falters in using the language of the dominant. She has been given the choice of setting herself apart and acting as a superior. As for her dominance in both houses, "enough other servants are introduced to increase still further our realization of Nelly's superiority, intellectual and moral" (Mathison, 1956, p. 108). On emotional side, however, she perfectly replaces almost all maternal roles. She is the one to whom almost all the characters return for consolation. After Catherine's death, she fills the place of the mistress in the Grange. She can perfectly act as an omniscient narrator who knows almost everything. But even she cannot preserve all that has passed prior to Lockwood's advent. What is received through Nelly is uncomplicated. The simplicity and rationality of her speech helps the reader move forth easily. The rational tone and the detached voice with which she imparts all that has happened give her narrative masculine or, in other words, symbolic features. These characteristics are further emphasized by attention to syntax, precision in the descriptions of the scenes and the verisimilitude which is present in her narrative.

Besides Nelly's narration, the complexity behind the apparent simplicity of the text calls for the reader's full cooperative attention. It has already been mentioned that the text of Wuthering Height's is quite like a dream. There are elisions in it. It comes to the reader in separate pieces. Once all parts of the puzzle are put together, one can comprehend it. This puzzle is not to be done alone. What Isabella starts Heathcliff finishes. What Catherine leaves unsaid, Nelly covers up. In short, what Lockwood starts as a narrative, comes to its end through all the characters' joining voices. "These narratives keep the story going when the demand of the plot requires Nelly to be absent." (Newman, 1990, p. 1033) But the ordering voice is Nelly's and the writing hand Lockwood's since these two are comfortably accommodated in the symbolic.

The time shifts, multiplication of narrators and narrators within narrators, the double plot, the effacement of the writer, and the absence of any trustworthy and knowing who clearly speaks for the 
writer are used strategically in Wuthering Heights to frustrate the expectations of a reader such as Lockwood. (Miller, 1963, p. 381)

Parts of Nelly's narrative include the letters sent and received among the characters. These letters are important in that they disclose part of the narrative that would otherwise escape Nelly's gaze. Isabella's letter is delivered to Nelly two months after her elopement with Heathcliff and shortly after her lodging in the Heights. The letter is important in expanding the narrator's outlook. Without Isabella's letter, the only evidence coming to the reader from the Heights at the time would be Nelly's short visit to Hareton. Isabella's letter, however, is a "relic of the dead [and is hence] precious" (Brontë, 1847, p. 173). It resembles Catherine's inscription in that it comes to the reader, untouched by Nelly's narrative. In addition to the information she gives to Nelly and readers alike in her letter, Isabella confirms Catherine's point of view regarding Heathcliff. Isabella's “Is Mr. Heathcliff a man?" (Brontë, 1847, p. 173) in her letter to Nelly is an echo of what Catherine has already tried to warn her about: "Tell her what Heathcliff is: an unreclaimed creature, without refinement, without cultivation; an arid wilderness of furze and whinstone...he's a fierce, pitiless, wolfish man." (Brontë, 1847, p. 141)

Catherine's daughter's correspondence with Linton follows another trait. These letters that are actually sent and received between Cathy and Heathcliff fulfill quite different aims. Heathcliff's words are deceitful. Through sending the letters, Heathcliff is able to set up the flames of love in Cathy's heart. His purpose, however, is to find a weak point to revenge on the Lintons. For Cathy, on the contrary, these letters define love through words. They are "more simple and more eloquent than her cousin's [actually Heathcliff's], very pretty and very silly." (Brontë, 1847, p. 259) This action becomes symbolic of Kristevan procedure of acquiring language to fill the absence of love in words. The words on the paper replace and compensate for the absence of a beloved that is kept far from her. Furthermore, through them, another dimension of the puzzle of the second pair's love story is also disclosed to the reader.

At any rate, Bronte shows the fake nature of words without true referents; though they can be used to replace the lost one, the wound never heals. The impossibility of accessing the true referent is further stressed through the incapability of the narrative in description of some scenes. Even Nelly's narrative does not record all scenes and feelings in words but rather portrays them. It seems that the wordless portrait is sufficient to convey the message language cannot express. At times in the story, deficiency of language is quite clear. The flow of words stops in such situations. Instead, pictures describing the states are presented. Instances of intensive feelings in characters are examples of this kind. The intensity of an emotion that is not to be expressed or is incompletely stated causes blocks or silent moments. Of these instances, one can refer to the scene in which Catherine is expressing her feelings for Heathcliff and Linton when she suddenly stops and cannot go on; "Nelly, I am Heathcliff! He's always, always in my mind: not as a pleasure, any more than I am always a pleasure to myself, but as my own being. So don't talk of our separation again: it is impracticable; and'.... She paused...." (Brontë, 1847, p. 122)

What she leaves unsaid obviously remains out of the touch of a narrative that encloses all other feelings. However, the nature of her feeling is understood by the reader. In her utterance, Catherine proves sure of what she says. Through what she leaves unsaid, the reader can grasp the nature of the connection between the two as a bond that cannot be revealed. Since the narrative is never to touch on the subjects like the nature of Catherine and Heathcliff's sexual relationship, Catherine should remain silent. The narrative avoids it because it is incestuous and not socially approved.

Brontë's peculiarity in depicting scenes of the two houses is exemplary. In the sketches she presents, Brontë is meticulous enough to show her reader how the fire within would be much preferred to the artificiality of the grandeur without. Though Catherine is ultimately doomed to death and Heathcliff to perdition, the reader does not find any points of objection to how their story could have been otherwise. And this is the trick of sublimation. Despite many negative hints to the romantic end of the story, the research aims to prove that Brontë has achieved her goal. Behind the cover of Hareton and Catherine, the two earthly lovers who comply with the norms, there looms the abject but fiery love of Catherine and Heathcliff. The memory of this love will haunt the readers just like the way the ghosts of "Heathcliff and a woman yonder" (Brontë, 1847, p. 366) haunt the text long after they are gone and buried under the layers of narrative.

In an answer to the question posed by Midttun in her interview about the writing subject, Kristeva states that: "To me, this [writing] is an experience of not belonging. When I write, I stand beside something, never in the middle of it. One keeps a distance. "A distance also to oneself as well, a kind of exile from oneself, where one in a sense is a stranger to oneself, in order to be able to write" (2006, p. 165).

This is exactly what Brontë has done. Brontë's writing delineates loss, desire for security and denial of loss. Through the pairs she creates, she represents her characters as metaphorical representatives of choices and results. Her personas take up various roles to indicate what each will come to. Not only Catherine's actions but also her very person is metaphoric of the writer's wish to state the need for eternal maternal love. At any rate, Brontë skilfully preserves her text and her person from the whirlwind of expression of such a need. Her sublimated text cries out the necessity of existence at the crossroads while praising the true beauty of the always desired nature deep down man's psyche.

\section{Conclusion}

As a subject in process capable of crossing the boundaries, the writer's mind is equipped with fresh ideas and her/his psyche with fresh energy. What matters in the writer's case is the ability to sublimate the forbidden and express it in the form of a danger-less, non-threatening commodity. The presence of two writing subjects in this novel helps delineate this notion further. Taking Catherine as representative of Brontë, a detailed analysis of Catherine's failure and death is compared and contrasted with Brontë's capability to maintain her identity as a subject in process. Moreover, the 
research negotiates the beauty and the simultaneous hold on the semiotic in case of Brontë who can fill her text with abundant images. In addition, examining the key metaphors in the text shows how sublimation occurs in a revolutionary mind like Brontë's. Through metaphors, Brontë establishes and demolishes the codes of an apparently accepted patriarchal world in the symbolic territory. She manages to destabilize the text by using apparently usual metaphors. The writer's use of metaphor along with her appearance in various roles and voices guarantees her laughter at this disruption without punishment. While she keeps on the safe side through her return to the shelter of language to write down her story of revolt and pleasure, Brontë deconstructs the ending of the story and its fake reform to salute the intensity of emotion she has welcomed earlier. Her two passionate revolutionary characters are ultimately doomed to death and replacement by a couple submitting to rules. Nonetheless, this is the first couple that is strictly remembered by the readers. The pleasure of such an experience for a reader who is an observer through the safe house of the symbolic joins and reflects the pleasure of the writer. However, the necessity of return to the shelter of the symbolic to write one's desire and to get rid of the danger of devastation through a longer sojourn in the semiotic realm is emphasized. This is accomplished as soon as the writer pens what passes deep down her mind and soul.

\section{References}

Brontë, Emily. (1847). Wuthering Heights. In David Daiches (Ed.) England: Penguin Books.

Buckler, William E. (1952). At Chapter VII of Wuthering Heights: A Key to Interpretation. Nineteenth- Century Fiction. 7(1), 80-86. Retrieved from <http://www.jstor.org/discover/10.2307/3044136>

Butler, Judith. ( 1989) The Body Politics of Julia Kristeva. Hapatia: Journal of French Feminist Philosophy. $3(3)$, 104 118. Retrieved from < http://www.jstor.org/discover/10.2307/3809790>

Esgalhado, Barbara Duarte. (2002) The Writing Subject: A Reconceptualization of the Psychological Self. Theory \& Psychology. 12(6), 777-94. Retrieved from <http://www.sagepublications.com>.

Gounelas, Ruth Parkin. (2001). Literature and Psychoanalysis. New York: Palgrave.

Homans, Margaret. (1992). The Name of the Mother in Wuthering Heights. In Linda Peterson (Ed). Wuthering Heights. ( $3^{\text {rd }}$ ed. pp. 341- 58) London: Bedford Books.

Homans, Margaret. (1978). Repression and Sublimation of Nature in Wuthering Heights

PMLA, 93 (1), 9-19. Retreived from <http://www.jstor.org/ stable/00308129>

Jacobs, Carol. (1979). Wuthering Heights: At the Threshold of Interpretation. Boundary 2, 7(3), 49-72. Retrieved from $<$ http://www.jstor.org/discover/10.2307/303164>

Kristeva, Julia. (1986). About Chinese Women. In Toril Moi (Ed.), The Kristeva Reader (pp. 138- 59). New York: Colombia University Press.

Kristeva, Julia. (1981). Desire in Language: A Semiotic Approach to Literature and Art. In Leon S. Roudiez (Ed.) Great Britain: Blackwell.

Kristeva, Julia. (1982). Powers of Horror. Trans. Leon S. Roudiez. New York: Colombia University Press.

Letche, John and Maria Margaroni. (2004). Julia Kristeva: Live Theory. London and New York: Continuuim.

Mathison, John K. (1956). Nelly Dean and the Power of Wuthering Heights. Nineteenth-

Century Fiction 11(2), (1956), 106-29. Retrieved from <http://www.jstor.org/discover/10.2307/3044112>

Midttun, Birgitte Huitfeldt. ( 2006). Crossing the Borders. An Interview with Julia Kristeva. Hypatia 21(4), 164-177. Retreived from $<$ muse.jhu.edu/journals $>$

Miller, J Hillis. (1963). Wuthering Heights: Repetition and the 'Uncanny'. In Wuthering Heights. (pp. 378-393) Sale and Dunn. New York: W.W. Norton and Company Inc.

Moi, Toril. (1985). Sexual/Textual Politics. $\left(2^{\text {nd }}\right.$ ed.) London and New York: Routledge.

Newman, Beth. (1990). The Situation of the Looker-On: Gender, Narration, and Gaze in Wuthering Heights. PMLA. 105(5), 1029-1041. Retrieved from <www.jstor.org/stable/462732>

Oliver, Kelly. (2003) The Crisis of Meaning. In Letche and Zournazi (Ed.) The Kristeva Critical Reader (pp. 36-54). Edinburg: Edinburg University Press Ltd.

Oliver, Kelly. (1993). Reading Kristeva: Unravelling the Double- bind. United States: Indiana University Press.

Vine, Steven. (1994). The Wuther of the Other in Wuthering Heights. Nineteenth-Century Literature. 49(3), 339-359. Retrieved from <www.jstor.org/stable/2933820>

Wion, Philip, K. ( 1992) The Absent Mother in Wuthering Heights. In Linda Peterson (Ed.) Wuthering Heights. (pp. 315-29) London: Bedford Books. 